\title{
Evaluation of Fetuin-A Protein and Some Inflammatory Biomarkers in Patients with Coronary Artery Disease
}

\author{
Amal M. Hassan ${ }^{1, *}$, Eman S. Saleh ${ }^{1}$, Sarkis K. Strak ${ }^{2}$ \\ ${ }^{1}$ Department of Clinical Laboratory Sciences, College Of Pharmacy, University Of Baghdad/ Baghdad/Iraq \\ ${ }^{2}$ Department of Medicine, College Of Medicine, University Of Basra/ Basra/Iraq \\ *Corresponding author: amalmalik81@yahoo.com
}

Received October 07, 2014; Revised October 28, 2014; Accepted November 02, 2014

\begin{abstract}
Background and Objectives: Coronary artery disease (CAD) is a state of insufficient supply of oxygenated blood to a part of myocardium. The most common cause of myocardial ischemia is atherosclerosis. Inflammation plays an important role in atherosclerosis and hence CAD. The principle inflammatory markers that believed to have a key position in the pathogenesis of CAD include fetuin-A protein, high sensitive C-reactive protein (hs-CRP), tumor necrosis factor-alpha (TNF- $\alpha$ ), and soluble intracellular adhesion molecule-one (sICAM-1). The aim of study was carried out to evaluate fetuin-A protein and some inflammatory biomarkers in patients with coronary artery disease. Subjects and Methods: Ninety subjects above forty year old; (45) patients with acute coronary syndrome (ACS); were divided in three groups: Unstable angina (UA), non-ST- elevation myocardial infarction (NSTEMI), and ST-elevation myocardial infarction (STEMI), all selected from Coronary Care Unit (CCU), and (45) apparently healthy age and sex matched subjects as controls. Five milliliters (5ml) of venous blood sample were drawn from each patient and healthy persons (controls), centrifuged to obtain serum, to be used for measuring the following variables: Fetuin-A protein, hs-CRP, TNF- $\alpha$, sICAM-1. Results: Fetuin-A protein was significantly lower, while hs-CRP, TNF- $\alpha$, and sICAM-1 were higher in patients. A low Fetuin-A protein level was inversely associated with increasing age. A high TNF- $\alpha$ level was associated with increased BMI. Conclusions: Lower serum Fetuin-A level, and higher serum levels of hs-CRP, TNF- $\alpha$, and sICAM-1 are associated with ACS. The future may be promising in rising of anew tests that use for evaluation of patients with suspected ACS.
\end{abstract}

Keywords: coronary artery disease, fetuin-A, hs-CRP, TNF- $\alpha$, sICAM-1

Cite This Article: Amal M. Hassan, Eman S. Saleh, and Sarkis K. Strak, "Evaluation of Fetuin-A Protein and Some Inflammatory Biomarkers in Patients with Coronary Artery Disease." American Journal of Pharmacological Sciences, vol. 2, no. 5 (2014): 87-92. doi: 10.12691/ajps-2-5-3.

\section{Introduction}

Coronary artery disease is a prevalent disease worldwide and is associated with significant morbidity and mortality. The most common cause of myocardial ischemia is atherosclerosis; which is a progressive inflammatory disorder of the arterial wall that is characterized by occlusion in the coronary artery(s) resulting in acute coronary syndrome (ACS); the STEMI, NSTEMI, and UA. Acute coronary syndrome (ACS) represents a life-threatening manifestation of atherosclerosis [1]. Inflammation is the key mechanism in the pathogenesis of atherosclerosis. It is difficult to measure the inflammatory process of atherosclerosis directly, however; there is a rising concern in biomarkers of inflammation [2].The principle inflammatory markers that believed to have a key position in the pathogenesis of CAD include fetuin-A protein, hsCRP, TNF- $\alpha$, and SICAM- 1 .

Fetuin-A protein is Alpha 2-Heremans Schmid glycoprotein (AHSG) of 62 kilo Dalton (KD).It belongs to the class of cysteine proteinase inhibitors, which are responsible for bone resorption $[3,4]$. It as a negative acute phase reactant synthesized by the liver cells, it is responsible for preventing calcium and phosphate precipitation in the blood by increasing their solubility and inhibiting calcium crystal growth [5]. Fetuin-A is participating in macrophage deactivation by being as antiinflammatory mediators [6]. According to the atherosclerosis lesions, calcium nodules might stimulate plaque rupture, as fetuin-A protein inhibit calcification so low fetuin-A levels are associated with atherosclerosis, inflammation and cardiovascular risk [5,6,7].

High sensitive C-reactive protein is a positive acute phase protein synthesized by the liver cells, its level rises in response to inflammation [8], hs-CRP release is triggered by various pro inflammatory stimulants as cytokines, oxidized LDL, and infectious agents [9]. In patients with coronary artery disease (CAD), increased level of hs-CRP is regarded as an important prognostic indicator for risk stratification in acute and recurrent attack as it is directly and actively participates in both atherogenesis and atheromatous plaque disruption [10].

Tumor necrosis factor-alpha (TNF- $\alpha$ ) is a proinflammatory cytokine, is mainly produced by monocytes or macrophages, it induces atherosclerosis in coronary arteries by increasing permeability of endothelial cells, promoting monocyte 
adhesion, inducing macrophage differentiation, and promoting foam cell formation [11]. TNF- $\alpha$ production is increased in unstable atherosclerotic plaques and in patients with acute myocardial infarction [12].

Intercellular adhesion molecule-one (ICAM-1), the CD54, is a transmembrane protein that is expressed on the surface of the immune cell and other cell types during inflammation. Both macrophages and endothelial cells produce ICAM-1 in response to inflammatory cytokines. Increased ICAM-1 expression augments Immune responses and leukocyte accumulation in inflamed tissues $[13,14]$.

Circulatory ICAM-1 which is the soluble ICAM-1 (sICAM-1) concentrations is useful indicators of the presence of atherosclerosis and the severity of coronary artery disease (CAD) [15].

\section{Subjects and Methods}

This study was carried out at Coronary Care Unit (CCU) at Basra Teaching Hospital and Basra General Hospital, Basra, Iraq, for the periods from $1^{\text {st }}$ September 2013 to $25^{\text {th }}$ April 2014. Ethical approval was obtained from ethics committee of the College of Pharmacy/ University of Baghdad. A total of ninety consecutive individuals were participated in this study meet the inclusion and exclusion criteria. Forty five patients with acute coronary syndrome (ACS), 23 males and 22 females, were divided into three sub-groups; 12 patients with UA (6 males \& 6 females), 12 patients with NSTEMI (6 males \& 6 females), and 21 patients with STEMI (11 males \& 10 females).Their ages ranged between (40-80; with a mean of a $59.3 \pm 10.1$ year). The diagnosis was made by a cardiologist depending on history, physical examination, ECG, and some biochemical parameters. Forty five apparently healthy asymptomatic subjects were participated as a control group for comparison; 23 males and 22 females. Their ages ranged between(40-80; with amean of a $58.8 \pm 11.2$ year).

Patients with chronic renal failure, newly diagnosed diabetes mellitus, and receiving thrombolytic therapy were excluded from the study.

Five milliliters of venous blood sample were drawn from each patient and healthy persons. The sample was transferred into a gel containing tube, and was left at room temperature for at least 30 minutes for clotting, then centrifuged at $1000 \mathrm{rpm}$ for 10 minutes to obtain a serum, which was separated and used for measuring the following variables: Fetuin-A protein, hs-CRP, TNF- $\alpha$, sICAM-1.

Measurement of fetuin-A, hs-CRP, TNF- $\alpha$, and sICAM-1 levels were performed by using commercially available Enzyme-linked Immune Sorbent Assay (ELISA) kits in accordance with the supplier's instructions. Serum fetuin-A was measured by Human Fetuin-A ELISA of Diametra ${ }^{\circledR} /$ Italy supplier. The principle of this test is based on the simultaneous binding of human fetuin-A by two different monoclonal antibodies, one coated on the microplate and the other conjugated with biotin. The results were expressed as nanogram per milliliter $(\mathrm{ng} / \mathrm{ml})$ [16]. HS-CRP ELISA kit of DRG ${ }^{\circledR} /$ USA supplier, is based on the principle of a solid phase, sandwich-format, and immune metric assay for the rapid determination of CRP in human serum. The results were expressed as microgram per milliliter $(\mu \mathrm{g} / \mathrm{ml})$ [17]. The TNF- $\alpha$ ELISA kit of
Beckman coulter ${ }^{\circledR} /$ Germany supplier, is a sandwich assay for the determination of TNF- $\alpha$ in serum. The results were expressed as picogram per milliliter $(\mathrm{pg} / \mathrm{ml})$ [18]. The sICAM-1 ELISA kit of $\mathrm{DRG}^{\circledR} / \mathrm{USA}$ is intended for quantitative determination of soluble ICAM-1 in human serum. sICAM-1 was assayed by a sandwich ELISA kit. The results were expressed as (ng/ml) [19]. Calculating body mass index (BMI); it is defined as the weight in kilograms divided by the square of the height in meters $\left(\mathrm{kg} / \mathrm{m}^{2}\right)$ according to the following equation: $\mathrm{BMI}=$ weight/height ${ }^{2}[20]$.

\subsection{Statistical Analysis}

All data analyzed using statistical package of social science (SPSS for windows version 20.0; Chicago, IL, USA) computer program. Statistical analysis included descriptive statistics, tables and figures (bar diagrams, scatter plots, and box plots). Statistical analysis included ttest, ANOVA test, and Person correlation coefficient test for quantitative variables, and Chi-square test for qualitative variables. In this analysis, the statistical significant association was determined, all $\mathrm{p}$ values were based on 2-sided tests, and $\mathrm{p}<0.05$ was considered statistically significant.

\section{Results}

\subsection{Markers of Inflammation}

The general characteristics of the study groups, as well as laboratory variables are shown in Table 1 and Table 2.

The study group included 90 subjects 45 patients (23 males \& 22 females) and 45 controls (23 males \& 22 females). As shown in Table 1, the age and gender were similar between controls and patients, the mean age for patients and controls were $59.3 \pm 10.1 ; 58.8 \pm 11.2$ years respectively. The mean value of BMI for patients and controls were $27.5 \pm 3.8 ; 24.6 \pm 2.8 \mathrm{~kg} / \mathrm{m}^{2}$ respectively, the BMI of controls was significantly lower than the BMI of patients, $\mathrm{P}<0.05$. The percentage of smokers was significantly higher in patients (53.3\%) than in controls (31.1\%), $\mathrm{P}<0.05$.

Table 1. General characteristic of studied patients and controls

\begin{tabular}{|lccc|}
\hline General characteristics & Controls (45) & Patients (45) & P value \\
\hline Age, mean \pm SD & $58.8 \pm 11.2$ & $59.3 \pm 10.1$ & 0.590 \\
\hline Gender, No. (\%) & & & 1.000 \\
Male & $23(51.1)$ & $23(51.1)$ & \\
Female & $22(48.9)$ & $22(48.9)$ & \\
\hline BMI, mean \pm SD & $24.6 \pm 2.8$ & $27.5 \pm 3.8$ & $0.001^{*}$ \\
\hline Smoking history, No. (\%) & & & $0.032^{*}$ \\
Smoker & $14(31.1)$ & $24(53.3)$ & \\
Non-smoker & $31(68.9)$ & $21(46.7)$ & \\
\hline
\end{tabular}

$* \mathrm{P}$ value $<0.05$ considered significant.

\begin{tabular}{|l} 
Table 2. Concentrations of serum parameters \\
\begin{tabular}{|lccc|}
\hline Serum parameters & $\begin{array}{c}\text { Controls (44) } \\
\text { Mean } \pm \text { SD }\end{array}$ & $\begin{array}{c}\text { Patients (45) } \\
\text { Mean } \pm \text { SD }\end{array}$ & P value * \\
\hline Fetuin-A, $\mathrm{ng} / \mathrm{ml}$ & $78.0 \pm 17.5$ & $61.6 \pm 18.3$ & 0.001 \\
\hline Hs-CRP, $\mu \mathrm{g} / \mathrm{ml}$ & $3.1 \pm 1.3$ & $4.0 \pm 1.6$ & 0.004 \\
\hline TNF-alpha, $\mathrm{pg} / \mathrm{ml}$ & $23.4 \pm 13.7$ & $43.6 \pm 20.4$ & 0.001 \\
\hline sICAM-1, ng/ml & $33.1 \pm 11.0$ & $38.7 \pm 11.2$ & 0.020 \\
\hline
\end{tabular}
\end{tabular}

$* \mathrm{P}$ value $<0.05$ considered significant. 
Table 2 reveals the serum levels of serum fetuin-A, serum hs-CRP, serum TNF-alpha, and serum ICAM-1 in controls and patients. Patients with CAD showed lower Fetuin-A levels than controls $(61.6 \pm 18.3$ Versus $78.0 \pm$ $17.5 \mathrm{ng} / \mathrm{ml}),(\mathrm{p}<0.05)$ as shown in (Figure 1$)$. Patients showed higher hs-CRP levels than controls $(4.0 \pm 1.6$
Vs.3.1 $\pm 1.3 \mu \mathrm{g} / \mathrm{ml}),(\mathrm{p}<0.05)$. The TNF- $\alpha$ levels in patients were higher than controls (43.6 \pm 20.4 Vs. $23.4 \pm$ $13.7 \mathrm{pg} / \mathrm{ml}),(\mathrm{p}<0.05)$. Patients showed higher levels of sICAM-1 than controls $(38.7 \pm 11.2$ Vs. $33.1 \pm 11.0 \mathrm{ng} / \mathrm{mL})$, $(\mathrm{p}<0.05)$.

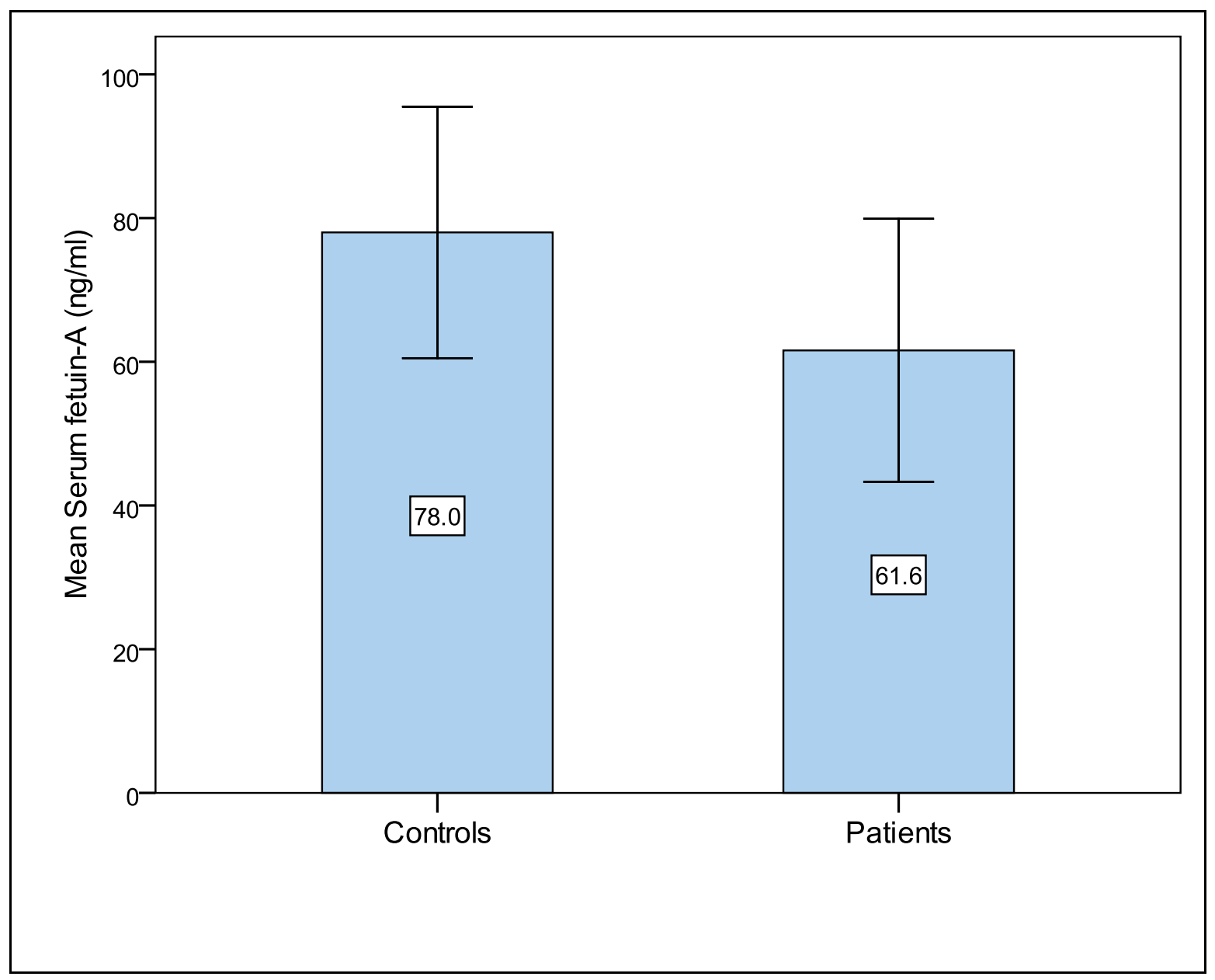

Figure 1. The mean $\pm \mathrm{SD}$ serum fetuin- $\mathrm{A}(\mathrm{ng} / \mathrm{ml})$ in controls and patients

Table 3. Biochemical parameters of the patients and controls

\begin{tabular}{|l|c|c|c|}
\hline Blood Parameters & $\begin{array}{c}\text { Patients (12) } \\
\text { UA } \\
\text { Mean } \pm \text { SD }\end{array}$ & $\begin{array}{c}\text { Patients (12) } \\
\text { NSTEMI } \\
\text { Mean } \pm \text { SD }\end{array}$ & $\begin{array}{c}\text { Patients (21) } \\
\text { STEMI } \\
\text { Mean } \pm \text { SD }\end{array}$ \\
\hline S. Fetuin -A protein $(\mathrm{ng} / \mathrm{ml})$ & $62.2 \pm 13.9 *$ & $60.8 \pm 17.3^{*}$ & $61.6 \pm 21.6^{*}$ \\
\hline S. hs-CRP $(\mu \mathrm{g} / \mathrm{ml})$ & $3.2 \pm 1.3$ & $4.4 \pm 2.1^{*}$ & $4.3 \pm 1.3^{*}$ \\
\hline S. TNF- $\alpha(\mathrm{pg} / \mathrm{ml})$ & $45.0 \pm 23.4^{*}$ & $44.8 \pm 19.9^{*}$ & $3.1 \pm 1.3$ \\
\hline S. ICAM $(\mathrm{ng} / \mathrm{ml})$ & $36.9 \pm 8.3$ & $40.7 \pm 10.1^{*}$ & $23.4 \pm 13.7$ \\
\hline
\end{tabular}

* Significant difference from controls, $\mathrm{p}<0.05$.

Biochemical parameters of the patients and controls are shown in (Table 3).

Data presented in Table 3 indicates that, Fetuin-A levels were lower in all subtypes of acute coronary syndrome $(\mathrm{p}<0.05)$.Patients with NSTEMI showed lower Fetuin-A levels than (STEMI and UA) as compared with controls (60.8 $\pm 17.3 ; \quad 61.6 \pm 21.6 ; 62.2 \pm 13.9 \mathrm{ng} / \mathrm{mL}$, respectively, $\mathrm{p}<0.05$ ) Vs. (control $78.0 \pm 17.5 \mathrm{ng} / \mathrm{mL}$ ), as shown in (Figure 2). According to the high sensitive Creactive protein, patients with STEMI and NSTEMI showed higher levels of hs-CRP than control subjects (4.3 $\pm 1.3 ; 4.4 \pm 2.1 \mu \mathrm{g} / \mathrm{ml}$, respectively, $\mathrm{p}<0.05$ ) Vs. (control $3.1 \pm 1.3 \mu \mathrm{g} / \mathrm{ml})$, Patients with UA showed no significant difference in serum hs-CRP levels ( $\mathrm{p}>0.05)$.
As presented in Table 3, patients with UA showed higher TNF- $\alpha$ levels than (NSTEMI and STEMI) as compared with controls $(45.0 \pm 23.4 ; 44.8 \pm 19.9 ; 42.1 \pm 19.9$ $\mathrm{pg} / \mathrm{mL}$, respectively, $\mathrm{p}<0.05$ ) Vs. (control $23.4 \pm 13.7$ $\mathrm{pg} / \mathrm{mL})$. Patients with STEMI and NSTEMI showed higher levels of sICAM-1 than control subjects (41.4 \pm 11.9; $40.7 \pm 10.1 \mathrm{ng} / \mathrm{ml}$, respectively, $\mathrm{p}<0.05$ ) Vs. (control $33.1 \pm 11.0 \mathrm{ng} / \mathrm{ml})$, Patients with UA showed no significant alteration in serum ICAM-1 levels ( $>0.05)$.

\subsection{Correlations Studies}

Pearson's correlation showed a significant negative association between serum level of fetuin-A and the age ( $\mathrm{r}$ $=-0.742, \mathrm{p}=0.001$ at the $\mathrm{p}<0.01$ level), as shown in 
(Figure 3). TNF- $\alpha$ showed a significant positive association $\quad$ with BMI $(r=0.357, \mathrm{p}=0.001$ at the $\mathrm{p}<0.01$ level).

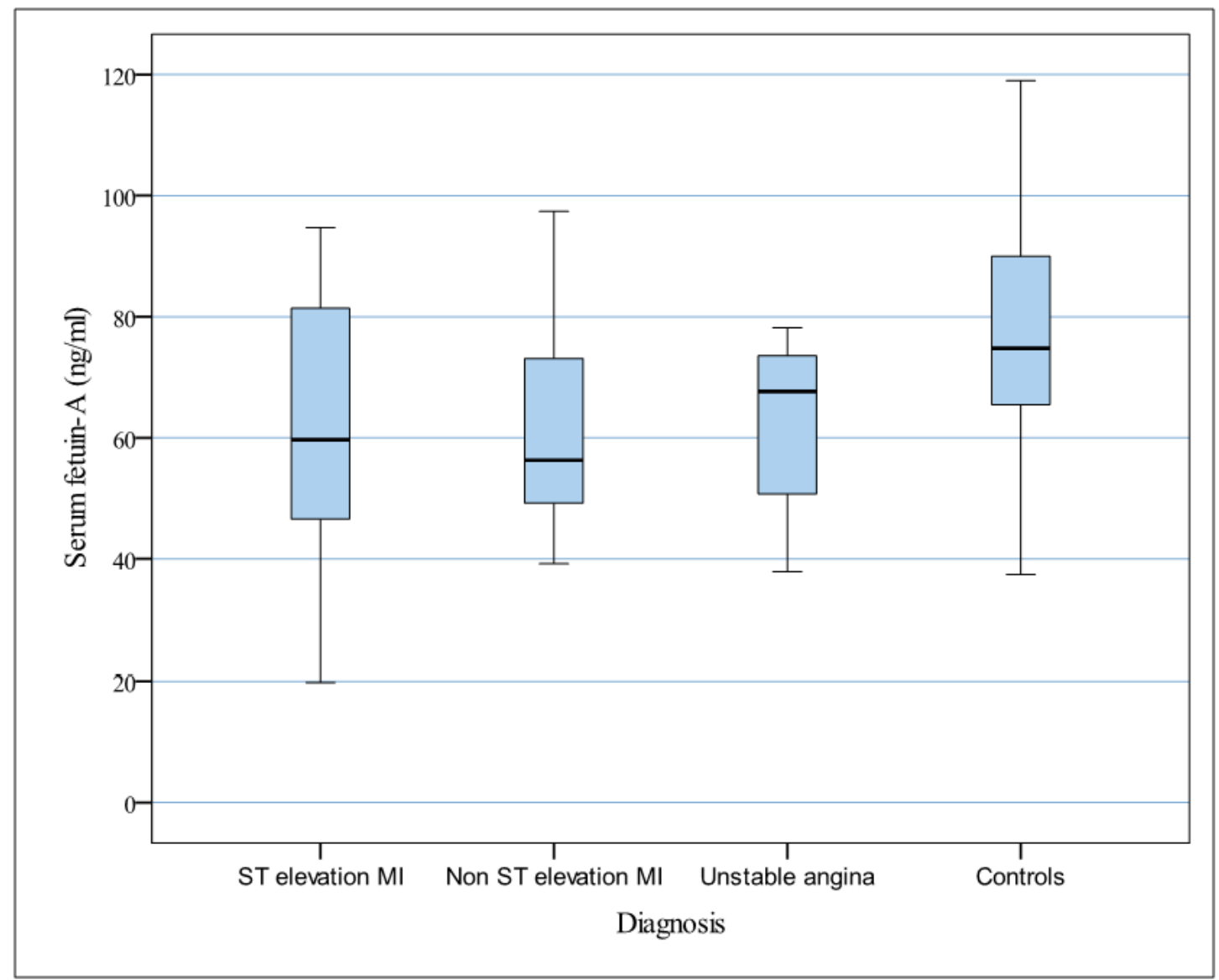

Figure 2. Serum fetuin-A (ng/ml) according to the diagnosis of patients and in controls

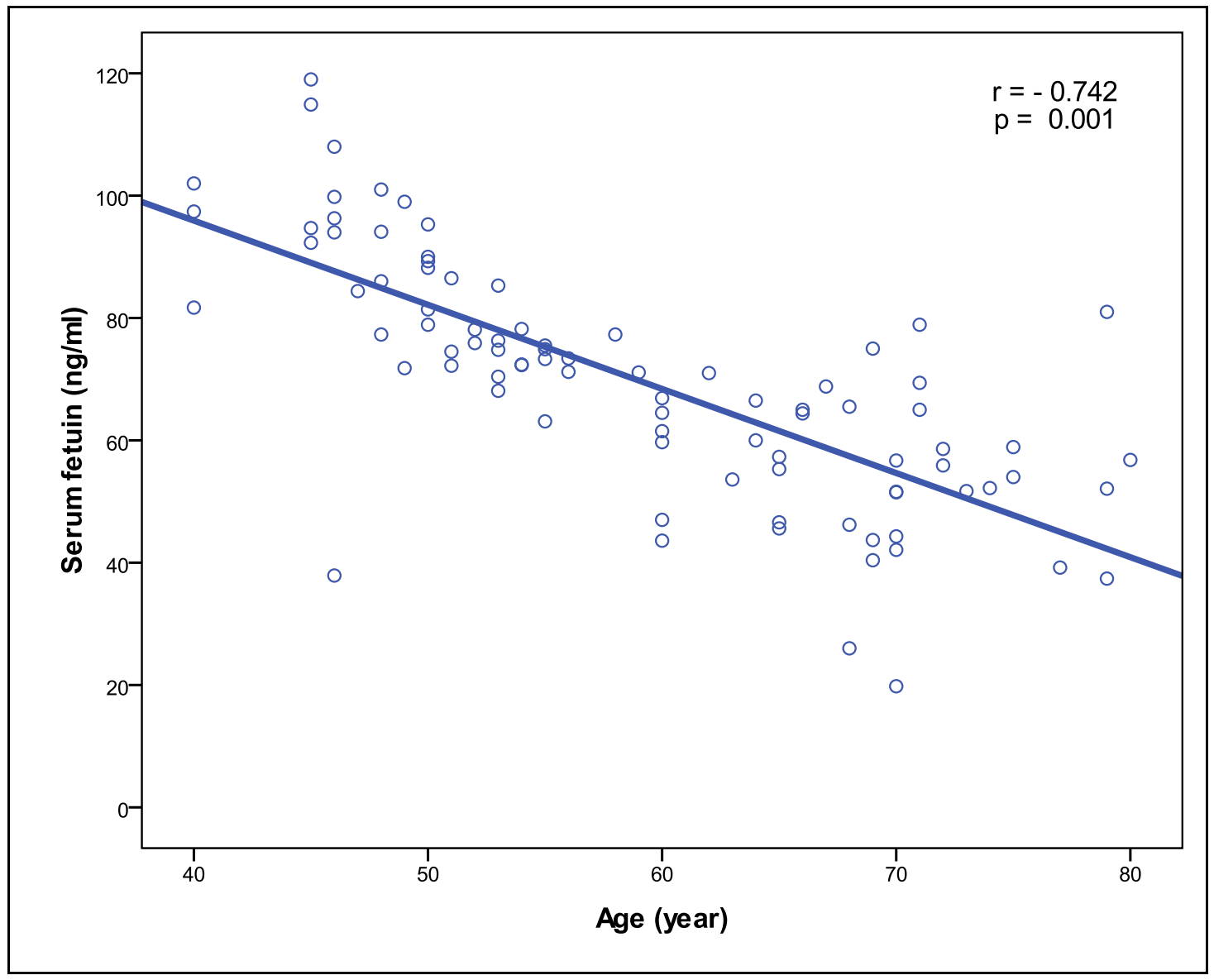

Figure 3. Relationship between age and serum fetuin-A level 


\section{Discussion}

Inflammation is seen in all stages of atherosclerosis and is the responsible cause of plaque rupture. In this study the fetuin-A protein was significantly decreased in patients with coronary artery disease, this result was the same finding in other studies that have documented a correlation between serum fetuin-A protein and CAD [21]. It still unknown mechanism that cause reduction in fetuin-A level during chronic inflammation (atherosclerosis). Fetuin-A protein is an anti-inflammatory mediator play an important role in preventing calcium deposition and inhibition of unwanted (vascular) calcification, so as fetuin-A level decreased, calcium deposition is increased that lead to narrowing of coronary artery; result in CAD and aortic calcification and stenosis [22,23,24]. Fetuin-A level was significantly lower in STEMI and NSTEMI and to a lesser extent in UA. This was supported by Lim et al., and Bilgiret al. findings which assumed that in (STEMI, and NSTEMI), fetuin-A has anti-inflammatory role in counter-regulating the innate immune response, that participates in macrophage deactivation, where as a low fetuin-A concentration will facilitate the ongoing inflammatory process and also the overproduction of cardio-toxic cytokines such as tumor necrosis factor which will expose patients to a high risk of recurrence of ACS $[21,22,23,24]$. No available data about the role and level of fetuin-A in UA. In the present study a low Fetuin-A protein level was inversely associated with increasing age.

High sensitive - CRP, was significantly elevated in patients with ACS; the in STEMI and NSTEMI. This was supported by the Sheikh A. study who demonstrated the higher level of hs-CRP in patients with NSTEMI and STEMI [10], however hs-CRP level was not significantly increase in patients with UA, this conflicted by Sheikh A. study who found a significant increase in hs-CRP level in UA [10].

In present study the low fetuin-A level combined with high concentrations of hs-CRP indicated a severe inflammatory process. This was supported by Lim P. et al. study [21].

Tumor necrosis factor-alpha (TNF- $\alpha$ ) is a proinflammatory cytokine, it induces the genes expression associated with inflammation, coagulation and proliferation so, it represent key mediators of endothelial dysfunction and atherosclerosis [25]. In the present study TNF- $\alpha$ was significantly increased in patients with ACS; the UA, NSTEMI, and STEMI. This was as the same as in Rajappa et al. study who found that TNF- $\alpha$ was increased significantly in patients with different subtypes of ACS [26]. In this study, TNF- $\alpha$ and BMI are positively associated, this result is supported by Swaroop J. study [27].

The sICAM-1 level was significantly elevated in patients with ACS and much more significant higher in NSTEMI and STEMI groups. This was consistent with numerous studies that have documented a correlation between sICAM-1 and CAD [15,28]. The result was demonstrated that sICAM-1 plays an important role in the development and progression of coronary atherosclerosis. sICAM-1 renders vulnerability to the atherosclerotic plaque by triggering the fissure, rupture, and subsequent thrombosis, leading to cause unstable angina and acute myocardial infarction. sICAM-1 level did not increase significantly in patients with UA. There is still limited information about the association of SICAM-1 with UA. Lu H. et al. found a significant increase in sICAM-1 level in UA [15], while Bossowska A. et al. study concluded that the evaluation of adhesion molecules (sICAM-1) in patients with heart diseases can be nonspecific markers of activity of inflammatory process in coronary vascular endothelium [29].

\section{Conclusion}

- Serum fetuin-A levels is significantly decreased in patients with acute coronary syndrome.

- Acute coronary syndrome is associated with elevated level of each of hs-CRP, TNF- $\alpha$, and s-ICAM- 1 .

- In future fetuin-A level and other inflammatory biomarkers mentioned above may be used to evaluate patients with suspected ACS.

\section{References}

[1] Hamm C., Agewall S., Bax J., Boersma E., Dudek D., Ohman M., et al.:ESC Guidelines for the management of acute coronary syndromes in patients presenting without persistent ST-segment elevation, European Heart Journal, 2011; 32: 2999-3054.

[2] Silvaa D., and de Lacerda A.: High-sensitivity C-reactive protein as a biomarker of risk in coronary artery disease, Revista Portuguesa de Cardiologia, 2012; 31(11):733-45.

[3] Cubukcuoglu T., Rasschaert N., Kacan C., Gul C. and Yavuz M.: Relationship between fetuin-A level and cardiovascular risk factors in peritoneal dialysis patients, Turkish Nephrology Dialysis and Transplantation Journal,2013; 22 (1): 78-9.

[4] Heiss A., Schwarz A., Westenfeld R., Ketteler M., Floege J, Schinke T., et al.: The serum protein $\alpha 2-$ Heremans-Schmid glycoprotein/fetuin-A is a systemically acting inhibitor of ectopic calcification, The Journal of Clinical Investigation, 2003; 112 (3): 357-66.

[5] Pateinakis P., Papagianni A., Douma S., Efstratiadis G. and Memmos D.: Associations of fetuin-A and osteoprotegerin with arterial stiffness and early atherosclerosis in chronic hemodialysis patients, BMC Nephrology Journal, 2013; 14: 122.

[6] Gangneux C., Daveau M., Hiron M., Derambure C., Papaconstantinou J. and Salier J.: The inflammation induced down regulation of plasma fetuin-A ( $\alpha 2 \mathrm{HS}$-glycoprotein) in liver results from the loss of interaction between long C/EBP isoforms at two neighboring binding sites, Nucleic Acid Research Journal, 2003; 31(20): 5957-70.

[7] Barrett-Connor E., Wassel C., Cummins K., Bergstrom J., Daniels L. and Laughlin G.: The associations of fetuin-A with subclinical cardiovascular disease in community-dwelling persons: the Rancho Bernardo Study, Journal of American College of Cardiology (JACC), 2011; 58 (23): 2372-79.

[8] Napoli M.: Elkind M., Godoy D., Singh P., Papa F., Popa-Wagner A., et al. Role of C-reactive protein in cerebrovascular disease, Expert Review Cardiovascular Therapy, 2011; 9 (12): 1565-84.

[9] Jialal I. and Devaraj S.: Inflammation and atherosclerosis the value of the high-sensitivity C-reactive protein assay as a risk marker, American Journal of Clinical Pathology, 2001; 116: 10815.

[10] Sheikh A., Yahya S., Sheikh N., and Sheikh N.: C-reactive protein as a predictor of adverse outcome in patients with acute coronary syndrome, Heart Views, 2012; 13(1): 7-12.

[11] Tintut Y., Patel J., Parhami F. and Demer L.: Tumor necrosis factor-alpha promotes in vitro calcification of vascular cells via the cAMP pathway, Circulation, 2000; 102(21): 2636-42.

[12] Padfield G., Din J., Koushiappi E., Mills N. and Newby D.: Cardiovascular effects of tumor necrosis factor $\alpha$ antagonism in patients with acute myocardial infarction: Afirst in human study, British Medical Journal (BMJ), 2013; 99: 1330-35.

[13] Yang Y., Jun C., Liu J., Zhang R., Joachimiak A., Springer T.,et al.: Structural basis for dimerization of ICAM-1 on the cell surface, Molecular Cell journal, 2004;14: 269-76. 
[14] Shaker O., Zahra A., Sayed A., Refaat A., El-Khaiat Z., Hegazy G., et al.: Role of ICAM-1 and E-selectin gene polymorphisms in pathogenesis of PAOD in Egyptian patients, Vascular Health and Risk Management, 2010: $6:$ 9-15.

[15] Lu H., Sheng Z., Wang Y. andZhang L.: Levels of soluble adhesion molecules in patients with various clinical presentations of coronaryatherosclerosis, Chines Medical Journal (Engl). 2010; 123 (21): 3123-6

[16] Ix J., Biggs M., Mukamal K., Kizer J., Zieman S., Siscovick D., et al.: Association of fetuin-a with incident diabetes mellitus in community living older adults: the cardiovascular health Study, Circulation, 2012;125(19): 2316-22.

[17] Mitra B. and Panja M.: High sensitive C-reactive protein: A novel biochemical markers and its role in coronary artery disease, The Journal of the Association of Physicians of India, 2005; 53: 25-32.

[18] De Totero D., Tazzari P., Capaia M., Montera M., Clavio M., Balleari E., et al.: CD40 triggering enhances fludarabine-induced apoptosis of chronic lymphocytic leukemia B-cells through autocrine release of tumor necrosis factor-alpha and interferongama and tumor necrosis factor receptor-I-II upregulation, Haematologica, 2003 ;88(2): 148-58.

[19] Postadzhiyan A., Tzontcheva A., Kehayov I. and Finkov B. Circulating soluble adhesion molecules ICAM-1 and VCAM-1 and their association with clinical outcome, troponin $\mathrm{T}$ and $\mathrm{C}-$ reactive protein in patients with acute coronary syndromes, Clinical Biochemistry, 2008; 41(3): 126-33.

[20] "BMI Classification". Global Database on Body Mass Index. World Health Organization. 2006. Retrieved July 27, 2012.

[21] Lim P., Moutereau S., Simon T., Gallet R., Probst V., Ferrieres J., et al.Usefulness of Fetuin-A and C-Reactive Protein Concentrations for Prediction of Outcome in Acute Coronary Syndromes (from the French Registry of Acute ST-Elevation NonST-Elevation Myocardial Infarction [FAST-MI]), The American Journal of Cardiology, 2013;111(1): 31-7.
[22] Reynolds J., Skepper J., McNair R., Kasama T., Gupta K., Weissberg P., et al.: Multifunctional roles for serum protein fetuin-a in inhibition of human vascular smooth muscle cell calcification, Journal of American Society of Nephrology, 2005;16(10): 2920-30.

[23] Afsar C., Yurdaku S., Muderrisoglu C., Demir B., Aslan A., Aral H., et al.: Association of serum fetuin-A levels with heart valve calcification and other biomarkers of inflammation among persons with acute coronary syndrome, Clinical and Investigative Medicine, 2012; 35 (4): 206-15.

[24] Bilgir O., Kebapcilar L., Bilgir F., Bozkaya G., and Yildiz Y., Pinar P., et al:Decreased Serum Fetuin-A Levels are Associated with Coronary Artery Diseases, Internal Medicine, 2010; 49: 1281-85.

[25] Steyers C., and Miller F.: Endothelial Dysfunction in Chronic Inflammatory Diseases, International Journal of Molecular Science, 2014; 15(7): 11324-49.

[26] Rajappa M, Sen SK., and Sharma A.: Role of pro-/antiinflammatory cytokines and their correlation with established risk factors in South Indians with coronary artery disease, Angiology, 2009; 60(4): 419-26.

[27] Swaroop J., Rajarajeswari D., and Naidu J.: Association of TNF- $\alpha$ with insulin resistance in type 2 diabetesmellitus, Indian Journal of Medical Research, 2012; 135: 127-130.

[28] Peng D., Zhao S., Li Y., Li J. andZhou H.: Elevated soluble CD40 ligand is related to the endothelial adhesion molecules in patients with acute coronary syndrome, International Journal of Clinical Chemistry, 2002; 319(1): 19-26.

[29] Bossowska A., Kiersnowska-Rogowska B.,Bossowski A., Galar B and Sowiński P.: Assessment of serum levels of adhesion molecules (sICAM-1, sVCAM-1, sE-selectin) in stable and unstable angina and acute myocardial infarction, PrzegladLekarski, 2003; 60(7):445-50. 